\title{
Role of Angiopoietins and Tie-2 in Diabetic Retinopathy
}

\author{
Nervana Khalaf ${ }^{1}$, Hazem Helmy ${ }^{2}$, Hany labib ${ }^{2}$, Iman Fahmy ${ }^{2}$, Mona Abd El Hamid ${ }^{3}$, Leqaa Moemen ${ }^{3}$
}

${ }^{1}$ Clinical Pathology Unit, Research Institute of Ophthalmology, Giza, Egypt

${ }^{2}$ Ophthalmology Department, Research Institute of Ophthalmology, Giza, Egypt

${ }^{3}$ Medical Biochemistry Unit, Research Institute of Ophthalmology, Giza, Egypt

\section{Type of article: Original}

\begin{abstract}
Objective: The aim of this study was to determine the serum levels of angiopoietin-1 (Ang-1), angiopoietin-2 (Ang-2), soluble vascular endothelial tyrosine kinase receptor (Tie-2) and vascular endothelial growth factor (VEGF), in the serum of type 2 diabetic patients having non-proliferative (NPDR) or proliferative diabetic retinopathy (PDR).

Methods: One hundred patients with type 2 diabetes mellitus were involved in this cross-sectional study. They were classified into 25 diabetic patients without retinopathy, 35 patients with NPDR and 40 PDR patients. The study was carried out in the outpatients clinic of the Research Institute of Ophthalmology, Giza, Egypt from August 2016 through May 2017. Serum VEGF, Ang-1, Ang-2 and Tie-2 receptor levels were assayed using enzyme linked immunosorbent assay (ELISA). Data were analyzed by SPSS version 20 and Microsoft Excel (Version 10) using ANOVA, Harman's single factor test, and Pearson's Product Moment Correlation.

Results: The serum levels of Ang-2 and VEGF were significantly elevated in NPDR groups and PDR group compared to diabetics without retinopathy groups $(\mathrm{p}<0.001)$. The serum levels of Ang-1 were significantly higher in the NPDR group compared to the diabetics without retinopathy groups $(p<0.01)$, while no significant difference was observed between the PDR and diabetics without retinopathy groups. Ang-1/Ang-2 ratio was the lowest in the PDR group compared to the NPDR and diabetics without retinopathy groups. The serum levels of Tie-2 were not significantly changed among the three studied groups, serum Ang-2 was positively correlated with VEGF and Tie-2 in the PDR and NPDR groups.

Conclusion: The angiopoietin /Tie system and VEGF are essential features in the commencement and development of PDR.

Keywords: Angiopoietins, Tie-2 receptor, Diabetic Retinopathy
\end{abstract}

\section{Introduction}

One of the most prevalent microvascular complications of diabetes is diabetic retinopathy (1). The initiation and progression of DR include various mechanisms such as: disorders in blood coagulation, oxidative stress and multiple neovascularization stimulating cytokines (2). Vascular endothelial growth factor (VEGF) is a key regulatory factor which participates in retinal and choroidal neovascularization and in excessive retinal vascular leakage (3). These types of microcirculatory disorder are the cause of retinal ischemia and the consequent upregulation of VEGF expression, and thus play an important role in the commencement of PDR (4). Angiopoietin are vascular growth factors involved in angiogenesis and vascular repair (5). Two major isoforms regulate vascular homeostasis, namely angiopoietin 1 (Ang-1) and angiopoietin 2 (Ang-2) (6). There are two other members of the angiopoietin family (Ang-3) and (Ang-4) (7). This Angiopoietin binds to the tyrosine kinase receptor with immunoglobulin and epidermal growth factor homology domain (Tie-2) on vascular endothelial cells (8). Tie-2 is a tyrosine kinase receptor predominantly existing on vascular endothelial cells which have a vital role in vascular stability. Ang-1 which are produced by perivascular cells, bind, and activate Tie-2, which lead to Tie-2, auto-phosphorylation and downstream signaling. The Tie-2 which is activated, increases survival of endothelial cells, adhesion and stability of

\section{Corresponding author:}

Professor Dr. Leqaa Moemen, Medical Biochemistry Unit, Research Institute of Ophthalmology, Egypt.

Tel: +201001033755, E-Mail: leqaa.moemen@yahoo.com

Received: June 18, 2017, Accepted: July 23, 2017, Published: August 2017

iThenticate screening: July 23, 2017, English editing: August 17, 2017, Quality control: August 20, 2017

(C) 2017 The Authors. This is an open access article under the terms of the Creative Commons Attribution-NonCommercialNoDerivs License, which permits use and distribution in any medium, provided the original work is properly cited, the use is non-commercial and no modifications or adaptations are made. 
cell junction which results in stabilizing vasculature. While Ang-2 are negative regulators induced by ischemia. Ang-2 inactivate Tie-2, destabilizing the vasculature and increasing the response to VEGF (9). Ang-1 and Ang-2 binds to the Tie-2 receptor and induces its phosphorylation, which affects physiological and pathological angiogenesis by Ang/Tie pathway (9). Angiopoietin-1 and 2 are endogenous ligands for the vascular endothelial receptor tyrosine kinas. Angiopoietin -1 signals vascular endothelial survival and the reorganization of blood vessels and also inhibits leukocyte migration and leakage into tissues. Angiopoietin -2 generally has an opposing action to angiopoietin -1 , and is released during vascular growth and in inflammation. The damage of the blood retinal barrier, which is induced by diabetes was inhibited by Ang-1 in a dose dependent manner (10). Accordingly, Ang -1 is protective against diabetic retinopathy, while it was found that Ang -2 induces vascular budding and increases vascular permeability, which leads to the pathological damage in retinopathy (11). They function in both an agonistic and antagonistic manner (12). The equilibrium between Ang-1 and Ang-2 and the signaling pathway induced by their binding to Tie-2, play a vital role in angiogenesis of the retina in diabetic retinopathy DR (13). The neovascularization marks the onset of PDR. Several studies have detected that the expression of Ang-2 and VEGF in the retina are unregulated in PDR. Ang-2 and VEGF work in a synergistic manner in promoting vascular permeability and stimulating retinal angiogenesis $(13,14)$. The aim of this study is to measure the serum levels of Ang-1, Ang-2, Tie-2 receptor and VEGF of diabetic patients with and without retinopathy, to investigate the role of the angiopoietin/Tie-2 system and VEGF in PDR.

\section{Material and Methods}

\subsection{Research design and participants}

This is a case-control study that included 100 type 2 diabetic patients whose ages ranged from 50 to 60 years. They were classified into 25 diabetic patients without retinopathy, 35 patients with NPDR and 40 patients with PDR, attending the outpatient clinic of the Research Institute of Ophthalmology, Giza, Egypt from August 2016 through May 2017. Exclusion criteria were liver or kidney dysfunction, cerebrovascular disease (including myocardial infection, cerebral infarction and peripheral artery disease, and uncontrolled hypertension. Also, any patients with other ocular conditions such as, cataract, glaucoma or uveitis were excluded from the study.

\subsection{Examinations}

Venous blood samples were collected on EDTA to measure HbAl c, and the other part was centrifuged, and serum was separated and stored at $-80{ }^{\circ} \mathrm{C}$ until assayed. Full ophthalmological examination was performed and medical history was taken for each patient including measuring the best corrected visual acuity and intraocular pressure, slit lamp examination to determine the anterior chamber depth by the goniolens and the presence or absence of iris neovascularization. Additionally, indirect ophthalmoscopy and bio microscopy to evaluate the grade of vitreous proliferation and determine the presence and nature of macular edema, fundus fluorescein angiography to differentiate between non proliferative and proliferative retinopathy, and laboratory assays of serum VEGF, Ang-1, Ang-2 and Tie-2 by enzyme linked immunosorbent assay (ELISA) were also carried out.

\subsection{Ethics of research:}

Written informed consent was obtained from all patients in this study. This study was approved by the Ethics Committee of the Research Institute of Ophthalmology (Egypt).

\subsection{Data analysis:}

Data were analyzed using descriptive statistics, ANOVA, Harman's single factor test, and Pearson's Product Moment correlation (r). Microsoft Excel (Version 10) and IBM@ SPSS $\odot$ Statistics version 20 (IBMC Corp., Armonk, NY, USA) were used for data analysis. The degree of association between the variables was assessed using Pearson's Product. Moment correlation ( $r$ ), where values of $\mathrm{p}<0.05$ were considered significant.

\section{Results}

Table 1, shows the patient's characteristics in the three studied groups including age, duration, FBS, HbA1c. The duration of diabetes was significantly longer in the PDR group compared to the NPDR and patients without retinopathy ( $\mathrm{p}<0.01, \mathrm{p}<0.05$ respectively). Table 2, shows serum levels of Ang-1, Ang-2, VEGF and Tie-2. The levels of Ang-2 and VEGF were significantly higher in the PDR than in NPDR and diabetics without retinopathy $(\mathrm{p}<0.01)$. While Ang-1 was not significantly changed in the PDR compared to diabetics without retinopathy, it was significantly higher in the NPDR compared to patients without retinopathy $(\mathrm{p}<0.05)$. No significant differences were detected in serum Tie-2 levels among the three studied groups ( $p>0.05)$. The ratio of Ang-1/Ang-2 in PDR groups were significantly lowered compared to diabetics without retinopathy and NPDR group $(\mathrm{p}<0.01)$. However, it was 
not significantly different between NPDR and diabetics without retinopathy ( $\mathrm{p}>0.05)$. The Ang-1/Ang-2 ratio in the PDR group was significantly decreased compared to the diabetics without retinopathy group. Also, Ang-2 was positively correlated with VEGF in PDR and NPDR groups $r=0.3,0.32$ respectively $(p<0.05)$. In the NPDR group, Ang-2 was positively correlated with Tie-2 and $\mathrm{r}=0.29(\mathrm{p}<0.05)$.

Table 1. Characteristics of Diabetic Patients Included in This Study.

\begin{tabular}{|l|l|l|l|l|}
\hline Variable & Diabetic without retinopathy; $\mathrm{n}=25$ & NPDR; $\mathrm{n}=35$ & PDR; $\mathrm{n}=40$ & $\mathrm{p}$-value \\
\hline Age & $52 \pm 12$ & $53 \pm 9$ & $55 \pm 10$ & NS \\
\hline Duration & $3 \pm 4.1$ & $4 \pm 3.2$ & $6 \pm 6.1$ & $<0.01$ \\
\hline FBS (mg/dl) & $180 \pm 55$ & $190 \pm 6.1$ & $227 \pm 8.4$ & $<0.01$ \\
\hline HbA1 C & $9.3 \pm 2.4$ & $9.2 \pm 2.2$ & $9.1 \pm 2.3$ & $<0.05$ \\
\hline
\end{tabular}

$\mathrm{p}<0.05$ significant, $\mathrm{NS}=$ not significant

Table 2. Serum Levels Ang-1, Ang-2, VEGF, Tie-2 and Ang-1/Ang-2 ratio Among the Three Studied Groups

\begin{tabular}{|l|l|l|l|l|}
\hline Variable & Diabetic without retinopathy; $\mathrm{n}=25$ & NPDR; $\mathrm{n}=35$ & $\mathrm{PDR} ; \mathrm{n}=40$ & $\mathrm{p}$-value \\
\hline Ang-1 $(\mathrm{ng} / \mathrm{ml})$ & $11.7 \pm 7.8$ & $12.1 \pm 9.1$ & $11.9 \pm 8.9$ & $<0.01$ \\
\hline Ang-2 $(\mathrm{ng} / \mathrm{ml})$ & $2.7 \pm 1.4$ & $4.4 \pm 2.51$ & $6.6 \pm 4.2$ & $<0.0001$ \\
\hline Ang-1/Ang-2 & 2.9 & 2.7 & 1.5 & $<0.001$ \\
\hline VEGF $(\mathrm{pg} / \mathrm{ml})$ & $160 \pm 41$ & $305 \pm 80$ & $541 \pm 290$ & $<0.0001$ \\
\hline Tie-2 $(\mathrm{ng} / \mathrm{ml})$ & $3.6 \pm 2.9$ & $3.7 \pm 3.2$ & $4.1 \pm 2.7$ & $>0.05$ \\
\hline
\end{tabular}

$\mathrm{p}<0.05$ significant

\section{Discussion}

Apoptosis, endothelial permeability and vascular inflammation play a vital role in diabetic retinopathy (15). Loss of pericytes and vasculopathy is followed by leukocyte adhesion and hyper permeability of the retinal microvasculature (16). Tissue ischemia leads to VEGF expression and angiogenesis leads to proliferative diabetic retinopathy (3). According to our findings, serum Ang-2 and VEGF levels were significantly higher in diabetic patients with NPDR and PDR compared to diabetic patients without retinopathy. Also, the levels of serum VEGF and Ang-2 were more elevated in the PDR group than in the NPDR group, suggesting that their levels are related to the progression of retinopathy. This is in agreement with many recent studies that showed that serum VEGF and Ang-2 are increased in diabetic retinopathy (18-20). Hackett et al. (14) found that Ang-2 can promote the initiation of new vessel formation in retinas as a response to ischemia. Also, Hammes et al. (21) postulated that the synergistic action of Ang-2 and VEGF promote hypoxia induced retinal angiogenesis, which is a pathological feature of PDR (20). Another study showed that Ang-2 can promote the neovascularization in the retina in response to hypoxia (21). Thus, Ang-2 is associated with pathological angiogenesis in patients with PDR (21). This study detected that Ang-2 and VEGF levels were significantly correlated with Tie-2 levels. We suggested that the Ang-2/Tie signaling system may interact with VEGF during the initiation of DR. Microvascular disorders lead to retinal ischemia, which increases VEGF expression. VEGF and hypoxia upregulate Ang-2 expression (22), Ang-2 interacts with VEGF to promote neovascularization (23). In the absence of VEGF, Ang-2 suppresses the ability of Ang-1 to phosphorylate the Tie-2 receptor causing vascular damage and endothelial cell apoptosis (24). Serum levels of Ang-2 and VEGF were significantly correlated with serum Tie-2 levels, suggesting that the Ang/Tie signaling may react with VEGF during the initiation of diabetic retinopathy (15). Microvascular disorders bring about retinal ischemia which upregulates VEGF expression. At the same time, VEGF and ischemia can upregulate the expression of Ang-2 $(18,19)$. Subsequently, VEGF and Ang-2 appear to interact together to encourage angiogenesis $(11,12)$. Several studies have detected that the effect of Ang-2 on vessels is dependent on the presence of VEGF $(11,12,17)$. This study showed that the serum Ang-1 level was significantly elevated in patients with NPDR compared to those without diabetic retinopathy and PDR patients. It was suggested that serum Ang-1 levels increase early in diabetic retinopathy as a compensatory mechanism to help cellular repair and preserve the integrity of the endothelial cell (25). Thus, promoting the stabilization and maturation of new micro vessels and the integrity of the micro vascular structure (26, 27). As Ang-1 and Ang-2 compete with each other for the Tie-2 receptor and have opposite functions concerning neovascularization, it is not sufficient to measure only one level of angiopoietins (28). So, to assess the equilibrium of ongoing angiopoietin process, we determined the ratio between the two antagonistic angiopoietins. The ratio between Ang-1 and Ang-2 decreased in the NPDR stage suggesting that the equilibrium between these angiopoietins have been changed in the early period of DR. In the PDR group, the ratio was almost half that in the NPDR group. Our results are in agreement with You et al. (28), who suggested that with the progression of DR, an 
increased level of Ang-2 and marked changes levels of Ang-1, shifts the equilibrium towards neovascularization. This Study detected that Tie-2 levels were not significantly different among three studied groups of patients. These results revealed that Tie-2 levels may not be associated with the progression of DR (29). The presence of Ang-2 and VEGF, suppresses the effect of Ang-1 in a competitive manner, thus breaching the endothelial cells' connection and consequently, leading to increased permeability of the vessel, inducing hypoxia-related retinal angiogenesis (30, 31).

\section{Conclusions}

In summary, this study detected that serum Ang-2 and VEGF are associated with the progression to PDR in type 2 diabetics. Ang/Tie system and VEGF, play an important role in the initiation and aggravation of PDR. Therefore, increasing Ang-1/Ang-2 ratio can help vessel integrity which may represent a new therapeutic target for treatment of diabetic retinopathy. Also, the Ang-1/Ang-2 ratios which influence the vascular integrity are still required to be established.

\section{Acknowledgments:}

The authors thank the Research Institute of Ophthalmology for supporting this research.

\section{Conflict of Interest:}

There is no conflict of interest to be declared.

\section{Authors' contributions:}

All authors contributed to this project and article equally. All authors read and approved the final manuscript.

\section{References:}

1) Yau JW1, Rogers SL, Kawasaki R; Meta-Analysis for Eye Disease (META-EYE) Study Group. Global prevalence and major risk factors of diabetic retinopathy. Diabetes Care. 2012 Mar;35(3):556-64. doi: 10.2337/dc11-1909, PMid: 22301125, PMCid: PMC3322721

2) Campochiaro PA. Molecular pathogenesis of retinal and choroidal vascular diseases. Prog Retin Eye Res. 2015 Nov;49:67-81. doi: 10.1016/j.preteyeres.2015.06.002, PMid: 26113211, PMCid: PMC4651818

3) Campochiaro PA, Aiello LP, Rosenfeld PJ. Anti-Vascular Endothelial Growth Factor Agents in the Treatment of Retinal Disease: From Bench to Bedside. Ophthalmology. 2016 Oct;123(10S):S78-S88. doi: 10.1016/j.ophtha.2016.04.056, PMid: 27664289

4) Kinnunen K, YLa-Herttuala S. Vascular endothelial growth factors in retinal and choroidal neovascular diseases. Ann Med. 2012 Feb;44(1):1-17. doi: 10.3109/07853890.2010.532150, PMid: 21284527

5) Feraud O, Mallet C, Vilgrain I. Expressional regulation of the angiopoietin-1 and -2 and the endothelialspecific receptor tyrosine kinase Tie2 in adrenal atrophy: a study of adrenocorticotropin-induced repair. Endocrinology. 2003 Oct;144(10):4607-15. doi: 10.1210/en.2003-0099, PMid: 12960064

6) Brkovic A, Pelletier M, Girard D, Sirois MG. Angipoietin chemotactic activities on neutrophils are regulated by PI-3K activation. J Leukoc Biol. 2007 Apr;81(4):1093-101. doi: 10.1189/jlb.0906580, PMid: 17215522

7) Eklund L, Saharinen P. Angiopoietin signaling in the vasculature. Exp Cell Res. 2013 May 15;319(9):1271-80. doi: 10.1016/j.yexcr.2013.03.011, PMid: 23500414

8) Joussen AM, Poulaki V, Tsujikawa A, Qin W, Qaum T, Xu Q, Moromizato Y, Bursell SE, Wiegand SJ, Rudge J, Ioffe E, Yancopoulos. GD, Adamis AP. Suppression of diabetic retinopathy with angiopoietin-1. Am J Pathol. 2002 May;160(5):1683-93. doi: 10.1016/S0002-9440(10)61115-7

9) Nambu H, Nambu R, Oshima Y, Hackett SF, Okoye G, Wiegand S, Yancopoulos G, Zack DJ, Campochiaro PA. Angiopoietin 1 inhibits ocular neovascularization and breakdown of the blood-retinal barrier. Gene Ther. 2004 May;11(10):865-73. doi: 10.1038/sj.gt.3302230, PMid: 15042118

10) Felcht M, Luck R, Schering A, Seidel P, Srivastava K, Hu J, Bartol A, et al. Angiopoietin-2 differentially regulates angiogenesis through TIE2 and integrin signaling. J Clin Invest. 2012 Jun;122(6):1991-2005. doi: 10.1172/JCI58832, PMid: 22585576, PMCid: PMC3366398

11) Sarlos S, Rizkalla B, Moravski CJ, Cao Z, Cooper ME, Wilkinson-Berka JL. Retinal angiogenesis is mediated by an interaction between the angiotensin type 2 receptor, VEGF, and angiopoietin. Am J Pathol. 2003 Sep;163(3):879-87. doi: 10.1016/S0002-9440(10)63448-7.

12) Peters S, Cree IA, Alexander R, Turowski P, Ockrim Z, Patel J, et al. Angiopoietin modulation of vascular endothelial growth factor: Effects on retinal endothelial cell permeability. Cytokine. 2007 Nov;40(2):14450. doi: 10.1016/j.cyto.2007.09.001, PMid: 17959386 
13) Watanabe D, Suzuma K, Suzuma I, Ohashi H, Ojima T, Kurimoto M, et al. Vitreous Levels of angiopoietin 2 and vascular endothelial growth factor in patients with proliferative diabetic retinopathy. Am J Ophthalmol. 2005 Mar;139(3):476-81. doi: 10.1016/j.ajo.2004.10.004, PMid: 15767056

14) Hackett SF, Ozaki H, Strauss RW, Wahlin K, Suri C, Maisonpierre P, et al. Angiopoietin 2 expression in the retina: upregulation during physiologic and pathologic neovascularization. J Cell Physiol. 2000 Sep;184(3):275-84. doi: 10.1002/1097-4652(200009)184:3<275::AID-JCP1>3.0.CO;2-7

15) Patel JI, Hykin PG ,Gregor ZJ, Boulton M, Cree IA. Angiopoietin concentrations in diabetic retinopathy. Br J Ophthalmol. 2005 Apr;89(4):480-3. doi: 10.1136/bjo.2004.049940, PMid: 15774928, PMCid: PMC1772595

16) Cai J, Kehoe O, Smith GM, Hykin P, Boulton ME. The angiopoietin/Tie-2 system regulates pericyte survival and recruitment in diabetic retinopathy. Invest Ophthalmol Vis Sci. 2008 May;49(5):2163-71. doi: 10.1167/iovs.07-1206, PMid: 18436850

17) Pfister F, Wang Y, Schreiter K, vom Hagen F, Altvater K, Hoffmann S, et al. Retinal overexpression of angiopoietin-2 mimics diabetic retinopathy and enhances vascular damages in hyperglycemia. Acta Diabetol. 2010 Mar;47(1):59-64. doi: 10.1007/s00592-009-0099-2, PMid: 19238311

18) Mandriota SJ, Pepper MS. Regulation of angiopoietin-2 mRNA levels in bovine microvascular endothelial cells by cytokines and hypoxia. Circ Res. 1998 Oct 19;83(8):852-9. doi: 10.1161/01.RES.83.8.852, PMid: 9776732

19) Oh H, Takagi H, Suzuma K, Otani A, Matsumura M, Honda Y. Hypoxia and vascular endothelial growth factor selectively up-regulate angiopoietin-2 in bovine microvascular endothelial cells. J Biol Chem. 1999 May 28;274(22):15732-9. doi: 10.1074/jbc.274.22.15732, PMid: 10336473

20) Holash J, Maisonpierre PC, Compton D, Boland P, Alexander CR, Zagzag D, et al. Vessel cooption, regression, and growth in tumors mediated by angiopoietins and VEGF. Science, 1999 Jun 18;284(5422):1994-8. doi: 10.1126/science.284.5422.1994, PMid: 10373119

21) Hammes HP, Feng Y, Pfister F, Brownlee M. Diabetic retinopathy: targeting vasoregression. 2011;60(1):916

22) Fiedler U, Reiss Y, Scharpfenecker M, Grunow V, Koidl S, Thurston G, et al. Angiopoietin-2 sensitizes endothelial cells to TNF-alpha and has a crucial role in the induction of inflammation. Nat Med. 2006 Feb;12(2):235-9. doi: 10.1038/nm1351, PMid: 16462802

23) Hang H, Bhat A, Woodnutt G, Lappe R. Targeting the ANGPT-TIE2 pathway in malignancy. Nat Rev Cancer. 2010 Aug;10(8):575-85. doi: 10.1038/nrc2894, PMid: 20651738

24) Gardizi M, Kurschat C, Riese A, Hahn M, Krieg T, Mauch C, Kurschat P. A decreased ratio between serum levels of the antagonistic angiopoietins 1 and 2 indicates tumour progression of malignant melanoma. Arch Dermatol Res. 2012 Jul;304(5):397-400. doi: 10.1007/s00403-012-1228-2, PMid: 22410864

25) Lip PL, Belgore F, Blann AD, Hope-Ross MW, Gibson JM, Lip GY. Plasma VEGF and soluble VEGF receptor Flt-1 in proliferative retinopathy: relationship to endothelial dysfunction and laser treatment. Invest Ophthalmol Vis Sci. 2000 Jul;41(8):2115-9. PMid: 10892852

26) Mahdy RA, Nada WM. Evaluation of the role of vascular endothelial growth factor in diabetic retinopathy. Ophthalmic Res. 2011;45(2):87-91. doi: 10.1159/000317062, PMid: 20720438

27) Lip P L, Chatterjee S, Caine G J. Hope-Ross M, Gibson J, Blann AD, Lip GY. Plasma vascular endothelial growth factor, angiopoietin-2, and soluble angiopoietin receptor tie-2 in diabetic retinopathy: effects of laser photocoagulation and angiotensin receptor blockade. Br J Ophthalmol. 2004 Dec;88(12):1543 -6. doi: 10.1136/bjo.2004.048587, PMid: 15548809, PMCid: PMC1772428

28) Qiao-Ying You,Fu-Yuan Zhuge,Qi-Qian Zhu and Xu-Wei Si, Effects of laser photocoagulation on serum angiopoietin-1, angiopoietin-2, angiopoietin-1/angiopoietin-2 ratio, and soluble angiopoietin receptor Tie-2 levels in type 2 diabetic patients with proliferative diabetic retinopathy. Int J Ophthalmol. 2014; 7(4): 648653. PMid: 25161936, PMCid: PMC4137200

29) Campochiaro PA and Peters KG. Targeting Tie2 for Treatment of Diabetic Retinopathy and Diabetic Macular Edema. Curr Diab Rep. Curr Diab Rep. 2016 Dec;16(12):126. doi: 10.1007/s11892-016-0816-5, PMid: 27778249

30) Moss A. The Angiopoietin: Tie 2 Interaction: A Potential Target for Future Therapies in Human Vascular Disease. Cytokine Growth Factor Rev. 2013 Dec;24(6):579-92. doi: 10.1016/j.cytogfr.2013.05.009, PMid: 23838360

31) Gnudi L. Angiopoietins and diabetic nephropathy. Diabetologia. 2016 Aug;59(8):1616-20. doi: 10.1007/s00125-016-3995-3, PMid: 27207083, PMCid: PMC4930459 